\title{
Mitochondrial DNA variation in the scallop Pecten maximus (L.) assessed by a PCR-RFLP method
}

\author{
CRAIG S. WILDING*, ANDY R. BEAUMONT \& JOHN W. LATCHFORD \\ School of Ocean Sciences, University of Wales (Bangor), Menai Bridge, Gwynedd LL59 5EY, U.K.
}

\begin{abstract}
Two PCR-RFLP mitochondrial DNA (mtDNA) markers were developed through the cloning and sequencing of mtDNA from the scallop Pecten maximus, and were used to study genetic differentiation of UK and Atlantic coast populations of this species. Although no distinct pattern of mtDNA haplotype frequencies was apparent and no diagnostic haplotypes were identified for any population, sequence divergence data provided convincing evidence that a $P$. maximus sample taken from Mulroy Bay, Eire, a semi-enclosed sea lough, was genetically differentiated from all other samples. However, this could not be unequivocally attributed to a restriction in gene flow, as the sample consisted of an ongrown single spatfall, which may not have been representative of the wild population. Despite the inability to separate populations on the basis of haplotype frequency, it was noteworthy that the frequency pattern of the commonest haplotype varied between sampling sites in a manner similar to that of allozyme allele frequencies in Aequipecten opercularis, a scallop species with a similar distribution and life history, for which there is evidence of population subdivision. Pecten maximus from St Brieuc Bay, reasoned to be a self-recruiting population from reproductive and physiological evidence, could not be separated from other populations using mtDNA markers. Further investigation of this population with alternative markers is warranted.
\end{abstract}

Keywords: length variation, mitochondrial DNA, Pecten maximus, PCR, population genetics, scallop.

\section{Introduction}

The scallop Pecten maximus (L.) has an extensive distribution throughout the coastal waters of northern Europe, ranging from Norway south to the Iberian Peninsula, and supports an important and valuable fishery (Ansell et al., 1991; Brand, 1991). Pecten maximus are most common between $20 \mathrm{~m}$ and $45 \mathrm{~m}$ on bottoms of sand, fine gravel or sandy gravel (Brand, 1991) in areas of favourable bottom stress (Dare et al., 1994). Such restrictions on suitable habitat result in a patchy distribution, with dense aggregations (beds) where scallops occur in sufficient densities for fishery exploitation (Sinclair et al., 1985). Although $P$. maximus larvae and postlarvae have a considerable planktonic dispersal capability (Beaumont \& Barnes, 1992), there is

*Correspondence: Department of Biology, University of Leeds, Leeds LS2 9JT, U.K. E-mail: bgycsw@leeds.ac.uk evidence that larval movement between beds, and hence gene flow, may be constrained. The evidence for this claim ranges from differences between populations in growth rate (Mason, 1983) and colour (Minchin, 1991) to potential hydrographic restrictions to gene flow between exploited populations detected using the North Sea water parcel following (NORSWAP) model (Dare et al., 1994). Scallops from a population in St Brieuc Bay, Brittany, present the clearest indication that gene flow between beds may be constrained, displaying a markedly different spawning cycle from neighbouring populations, the characteristics of which are maintained following reciprocal transplantation (Paulet et al., 1988; Cochard \& Devauchelle, 1993; Mackie \& Ansell, 1993).

Past efforts to identify differences between $P$. maximus populations using allozyme frequency data have, however, proved unfruitful (Beaumont et al., 1993). In contrast, for Aequipecten opercularis, a 
scallop species with a similar distribution and life history, there are significant allele frequency differences between populations, and separation of the St Brieuc population on the basis of allozyme data (Beaumont, 1982). As A. opercularis has an increased capacity for larval dispersal relative to $P$. maximus owing to its enhanced byssal drifting capability (Beaumont \& Barnes, 1992), gene flow in $P$. maximus is a priori expected to be lower and, thus, genetic differentiation greater. If $P$. maximus is indeed genetically structured, then the inability to separate populations using allozyme methodologies may be explainable by the action of balancing selection at allozyme loci, which has been suggested as being capable of maintaining similar population allele frequencies in spite of negligible gene flow (Karl \& Avise, 1992).

DNA-based methodologies targeted at essentially neutral loci are now being used to challenge some of the results based on allozyme data (Mitton, 1994). The marker of choice for the majority of population level comparisons has been the mitochondrial DNA (mtDNA), and restriction fragment length polymorphism (RFLP) analysis of the mtDNA molecule has been widely applied to marine species (Ovenden, 1990). However, recent work has shown that in many scallops (Snyder et al., 1987; Gjetvaj et al., 1992; Repin \& Brykov, 1992; Boulding et al., 1993), including $P$. maximus (Rigaa et al., 1993), mtDNA length differences between individuals and species are extensive. Pecten maximus mtDNA is variable in length as a result of varying numbers of a tandemly repeated $1.55 \mathrm{~kb}$ element (Rigaa et al., 1993, 1995). This may complicate mtDNA RFLP studies, as the separation of fragment pattern differences because of restriction site losses and gains from those caused by length differences can prove difficult (Moritz et al., 1987; Boulding et al., 1993; Wilding, 1996). This problem can be avoided through examination of RFLPs in defined sections of mtDNA amplified by the polymerase chain reaction (PCR). PCR-RFLP has proved to be a useful technique for systematic studies and species identification (e.g. Chow \& Inoue, 1993) and in population analysis (Cronin et al., 1993, 1994; Bartlett \& Davidson, 1995; Hall \& Nawrocki, 1995).

To date, there has been no study examining population level DNA variability within $P$. maximus. Here, we demonstrate that specific primers designed for PCR-RFLP can be useful in the examination of population genetic structure and we apply the method to $P$. maximus from Britain, Eire and northern France.

\section{Methods}

\section{Sampling}

Twelve populations of $P$. maximus were sampled by dredge fishing or scuba diving (see Fig. 1). All were samples of adult animals. Mulroy Bay individuals had been collected as wild spat, ongrown to approximately $2 \mathrm{~cm}$ in Mulroy Bay, then transplanted to Kilkieran Bay. Mortality was negligible (Dr G. Burnell, University College, Cork, personal communication). Animals were received live and maintained in running seawater until dissection, or dissected and frozen $\left(-70^{\circ} \mathrm{C}\right)$ until use. The Polperro and Lyme Bay samples were received frozen at $-20^{\circ} \mathrm{C}$ and used after thawing of tissue.

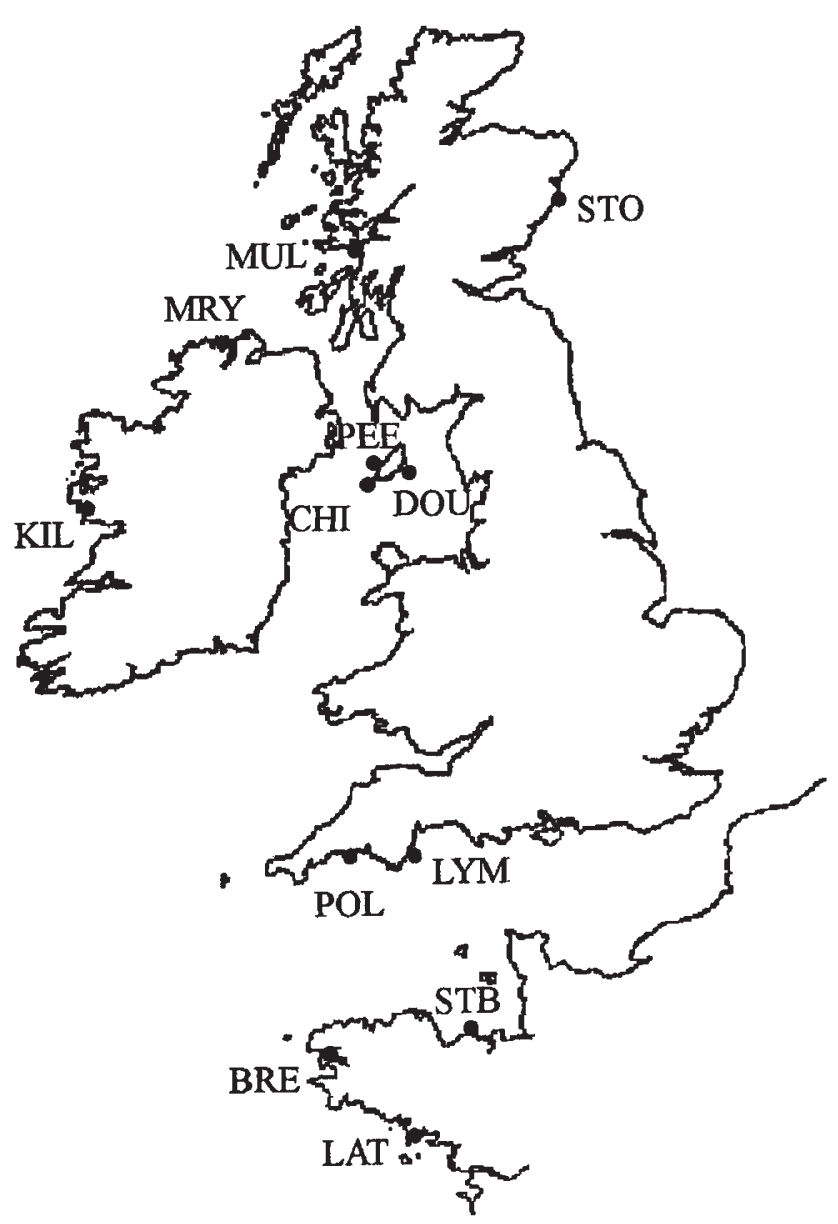

Fig. 1 Collection locations for Pecten maximus samples. DOU, Douglas; PEE, Peel; CHI, Chicken Rock; STO, Stonehaven; MUL, Mull; LYM, Lyme Bay; POL, Polperro; MRY, Mulroy Bay (transplanted to and ongrown in Kilkieran Bay); KIL, Kilkieran Bay; STB, Nerput, St Brieuc Bay; BRE, Tinduff, Daoulas Bay, Rade de Brest; LAT, La Trinité sur Mer. 


\section{DNA extraction}

Mitochondrial DNA of individual animals was extracted from approximately $5 \mathrm{~g}$ of adductor muscle using the technique of Snyder et al. (1987) adapted to include the modifications of Boulding et al. (1993) and a CTAB (hexadecyltrimethyl ammonium bromide) incubation to remove polysaccharides (Fisher \& Skibinski, 1990). MtDNA was resuspended in $50 \mu \mathrm{L}$ of $\mathrm{dH}_{2} \mathrm{O}$.

Genomic DNA was isolated from approximately $50 \mathrm{mg}$ of tissue, homogenized in $300 \mu \mathrm{L}$ of $\mathrm{CTAB}$ buffer (100 mм Tris- $\mathrm{HCl}$, pH 8.0, $1.4 \mathrm{M} \mathrm{NaCl}, 20 \mathrm{~mm}$ EDTA, 2 per cent CTAB, 0.2 per cent 2 -mercaptoethanol), then incubated at $65^{\circ} \mathrm{C}$ for $30-60 \mathrm{~min}$ after the addition of $15 \mu \mathrm{L}$ of $10 \mathrm{mg} \mathrm{mL}^{-1}$ proteinase $\mathrm{K}$. The lysate was then extracted once with chloroformisoamyl alcohol (24:1), once with phenol-chloroform-isoamyl alcohol (24:24:1) and once with chloroform-isoamyl alcohol. DNA was precipitated with 0.1 volumes of $3 \mathrm{M} \mathrm{NaOAc}$ and 1 volume of isopropanol, air-dried and resuspended in $100 \mu \mathrm{L}$ of $\mathrm{dH}_{2} \mathrm{O}$.

\section{Cloning, sequencing and primer design}

A number of restriction enzymes were applied to $P$. maximus mtDNA in order to identify fragments suitable for cloning, sequencing and primer design (Wilding, 1996). Two fragments of mtDNA, which showed no evidence of length variation after restriction digest screening of a number of individuals, were chosen for sequencing; a 2 kb EcoRI-HindIII fragment and a $3.85 \mathrm{~kb}$ HindIII-HindIII fragment. MtDNA for ligation was purified as above from a single animal except that two bouts of sucrose gradient centrifugation (Snyder et al., 1987) were used to ensure complete separation of mitochondria from nuclei. Restriction enzyme-treated mtDNA was ligated into pBluescript $\mathrm{KS}^{+}$(Stratagene) using standard protocols (Sambrook et al., 1989) and used to transform competent XL1-blue E. coli. Recombinant colonies were identified using $\beta$-galactosidase complementation, and inserts of the correct size were detected via restriction enzyme digestion of mini-prepped DNA (Holmes \& Quigley, 1981). Vector DNA containing the desired insert was further purified using Promega's Wizard mini-preps, and the ends were sequenced using Pharmacia's T7 sequencing kit following the manufacturer's specifications. PRIMER (The Lander Laboratory, Cambridge, MA, U.S.A.) was used to identify PCR primers from these sequences, accepting default conditions except primer length (20-25) and melting temperature $\left(60^{\circ} \mathrm{C}\right)$. Primers were synthesized by Cruachem, Glasgow. Primer sequences were as follows.

Primer pair Pma1, target $2 \mathrm{~kb}$ EcoRI-HindIII fragment $\left(5^{\prime}-3^{\prime}\right)$ :

\section{TTTTAAGGAGGTAATCGCTATTCG}

\section{CAGCAATCTGTATGGGTAGAACC}

Primer pair Pma2, target 3.85 kb HindIII-HindIII fragment $\left(5^{\prime}-3^{\prime}\right)$ :

\section{TTTTATGTGGTGGTATTGTTGAGG \\ ATAGGATAGTCTGGAATACGACGC}

\section{Amplification and restriction digestion of PCR products}

Amplification using the Pma1 primer pair was undertaken in a $50 \mu \mathrm{L}$ total volume of $50 \mathrm{~mm} \mathrm{KCl}$, $10 \mathrm{~mm}$ Tris- $\mathrm{HCl}$ (pH 9.0), $2.5 \mathrm{~mm} \mathrm{MgCl}_{2}, 0.1$ per cent (v/v) Triton X-100, $200 \mu \mathrm{M}$ each dNTP, $25 \mathrm{pmol}$ of each primer and $1 \mathrm{U} \mathrm{Taq}$ (Promega). Cycle parameters of $3 \mathrm{~min}$ at $94^{\circ} \mathrm{C}$, followed by 35 cycles of $45 \mathrm{~s}$ at $94^{\circ} \mathrm{C}, 30 \mathrm{~s}$ at $52^{\circ} \mathrm{C}$ and $2 \mathrm{~min}$ at $72^{\circ} \mathrm{C}$ with a final extension time of $7 \mathrm{~min}$ at $72^{\circ} \mathrm{C}$ were used. The Pma2 fragment was amplified in a $50 \mu \mathrm{L}$ volume with $50 \mathrm{~mm} \mathrm{KCl}, 10 \mathrm{~mm}$ Tris- $\mathrm{HCl}(\mathrm{pH} 8.8), 2.5 \mathrm{~mm}$ $\mathrm{MgCl}_{2}, 0.1$ per cent (v/v) Triton X-100, $200 \mu \mathrm{M}$ each dNTP, 25 pmol of each primer, $1 \mathrm{U}$ Tbr polymerase (NBL) and $1 \mathrm{U} \mathrm{Taq}$ extender (Stratagene). Cycle parameters of $3 \mathrm{~min}$ at $94^{\circ} \mathrm{C}$ and 40 cycles of $1 \mathrm{~min}$ at $94^{\circ} \mathrm{C}, 1 \mathrm{~min}$ at $56^{\circ} \mathrm{C}$ and $5 \mathrm{~min}$ at $72^{\circ} \mathrm{C}$ with a final extension time of $10 \mathrm{~min}$ at $72^{\circ} \mathrm{C}$ were used. DNA templates consisted of $1 \mu \mathrm{L}$ of a 1:10-1:100 dilution of mtDNA or $1 \mu \mathrm{L}(100-500 \mathrm{ng})$ of genomic DNA (gDNA). Restriction digestion was performed on 5 $\mu \mathrm{L}$ aliquots of successful amplifications in $20 \mu \mathrm{L}$ total volume using 1-2 U of enzyme. The enzymes, AluI, CfoI, DraI, HaeIII, HinfI, MspI, RsaI, Sau3AI and TaqI, were used in trial screenings to assess variability. Digestion products were separated on 1.4 per cent agarose gels.

\section{Statistical analysis}

For each individual, a composite haplotype described the patterns generated by multiple restriction endonucleases and, for each RFLP pattern, the type of site change responsible could be ascertained from digestion patterns and attributed to one, or occasionally two, site changes. Restriction mapping was not performed. Using information on the number of composite haplotypes within each popu- 
lation and a presence/absence matrix of restriction sites, data were analysed using REAP (McElroy et al., 1992). The DA option was used to compute haplotype diversity and nucleotide diversity both within populations and between populations, corrected for within-population diversity (Nei, 1987). Nucleotide diversity values were used as input for the SAHN and TREE options of NTSYS (Rohlf, 1990) in order to construct a UPGMA dendrogram. Sequence divergence estimates between haplotypes were used as input for NEIGHBOR in PHYLIP to produce a UPGMA dendrogram of haplotype relatedness. The MONTE option of REAP was used to test for heterogeneity of haplotype numbers via $\chi^{2}$ using a Monte Carlo procedure with 10000 randomizations, following the method of Roff \& Bentzen (1989) to avoid problems associated with empty cells and small sample sizes. Chi-squared tests were performed over all data, in pairwise comparisons of populations and on a single enzyme haplotype basis. $\theta$, a haploid analogue of $F_{\text {ST }}$, was calculated using FSTAT (Goudet, 1995).

\section{Results}

Two regions of $P$. maximus mtDNA were successfully cloned, a $2 \mathrm{~kb}$ EcoRI-HindIII fragment and a 3.85 kb HindIII-HindIII fragment, from which sequence was obtained and primers designed to facilitate PCR amplification. The location of the $3.85 \mathrm{~kb}$ HindIIIHindIII fragment is evident from the restriction map of Rigaa et al. (1993). Using NsiI, the recognition sequence of which is within the sequence identified from forward primed sequencing of the $2 \mathrm{~kb} E c o \mathrm{RI}-$ HindIII fragment, and which cleaves $P$. maximus mtDNA only once (Wilding, 1996), the location and orientation of this fragment was also confirmed (Fig. 2). Neither of the fragments, which proved to be contiguous, extends into the length-variable domain noted by Rigaa et al. (1993).

These primers were applied under optimized conditions to both pure mtDNA and crude genomic DNA isolated from scallops from all sampling sites. There was no evidence of length variation in amplified DNA. Amplification with Pma1 was consistently successful. However, after initial success, amplification using Pma2 later failed and could not be resurrected, in spite of further optimization, purchase of new primers or change of manufacturers of Taq or dNTPs.

\section{Restriction analysis of amplified products}

Six of the nine enzymes screened against the Pma1 product identified polymorphisms at the 0.95 level
(CfoI, HinfI, MspI, RsaI, Sau3AI and TaqI). Seven enzymes produced polymorphic patterns when screened against the Pma2 fragment (DraI, HaeIII, HinfI, MspI, RsaI, Sau3AI and TaqI). RFLP patterns are detailed in Wilding (1996). No differences were detected in RFLP patterns generated from amplification using gDNA or pure mtDNA templates, suggesting that nuclear copies of the studied mtDNA regions (Zhang \& Hewitt, 1996) had not been amplified. For the Pma1-amplified fragment, a total of 30 variable restriction sites were recognized and 59 different composite haplotypes were identified (Table 1). Although screening with the Pma2 primer pair was restricted, variation within the limited sample screened was also high, with 36 composite haplotypes identified (Table 2). Screening was more extensive for the Pma1 fragment, and data from this fragment are concentrated on. However, the limited quantity of data for the Pma2 fragment did not alter the conclusions from these data.

Although there is variation in the frequency of Pma1 composite haplotypes (Table 1), for example the frequency of the common haplotype

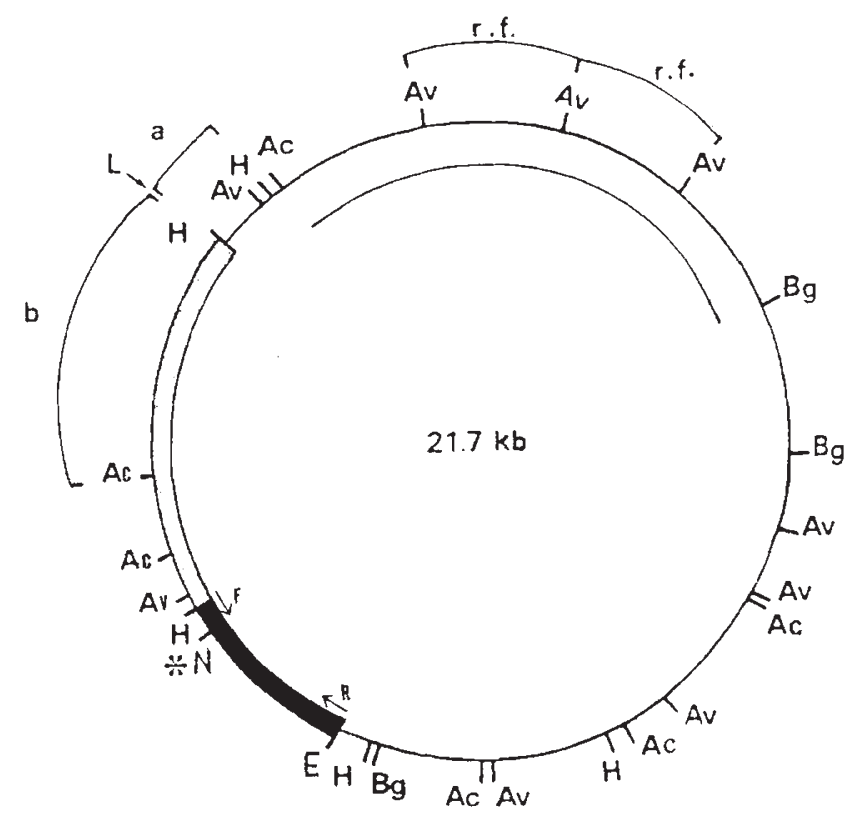

Fig. 2 Circular restriction map of Pecten maximus mtDNA as published by Rigaa et al. (1993) with additional information on the location of the $2 \mathrm{~kb}$ and $3.85 \mathrm{~kb}$ fragments isolated in this study. Ac, $A c c \mathrm{I}$; $\mathrm{Av}, A v a \mathrm{I} ; \mathrm{Bg}, B g l \mathrm{II} ; \mathrm{E}$, EcoRI (only one site mapped); H, HindIII; N, NsiI. Open region: $3.85 \mathrm{~kb}$ HindIII-HindIII fragment. Heavy shading: $2 \mathrm{~kb}$ EcoRI-HindIII fragment. F, location of Pma1 primer designed from forward-primed sequence. R, location of Pma1 primer designed from reverse-primed sequence. Inner arc indicates length-variable domain. 
(AAAAAA) varies widely between sample sites, accounting for between 25 per cent and 53 per cent of all composite haplotypes, no significant differences in haplotype numbers could be detected between populations using $\chi^{2}$ analysis, either tablewise (37.3 per cent of pseudo $\chi^{2}$-values from the randomized data were higher than those generated from the real data), in pairwise comparisons of

Table 1 Pma1-amplified mitochondrial DNA haplotypes in 12 populations of Pecten maximus

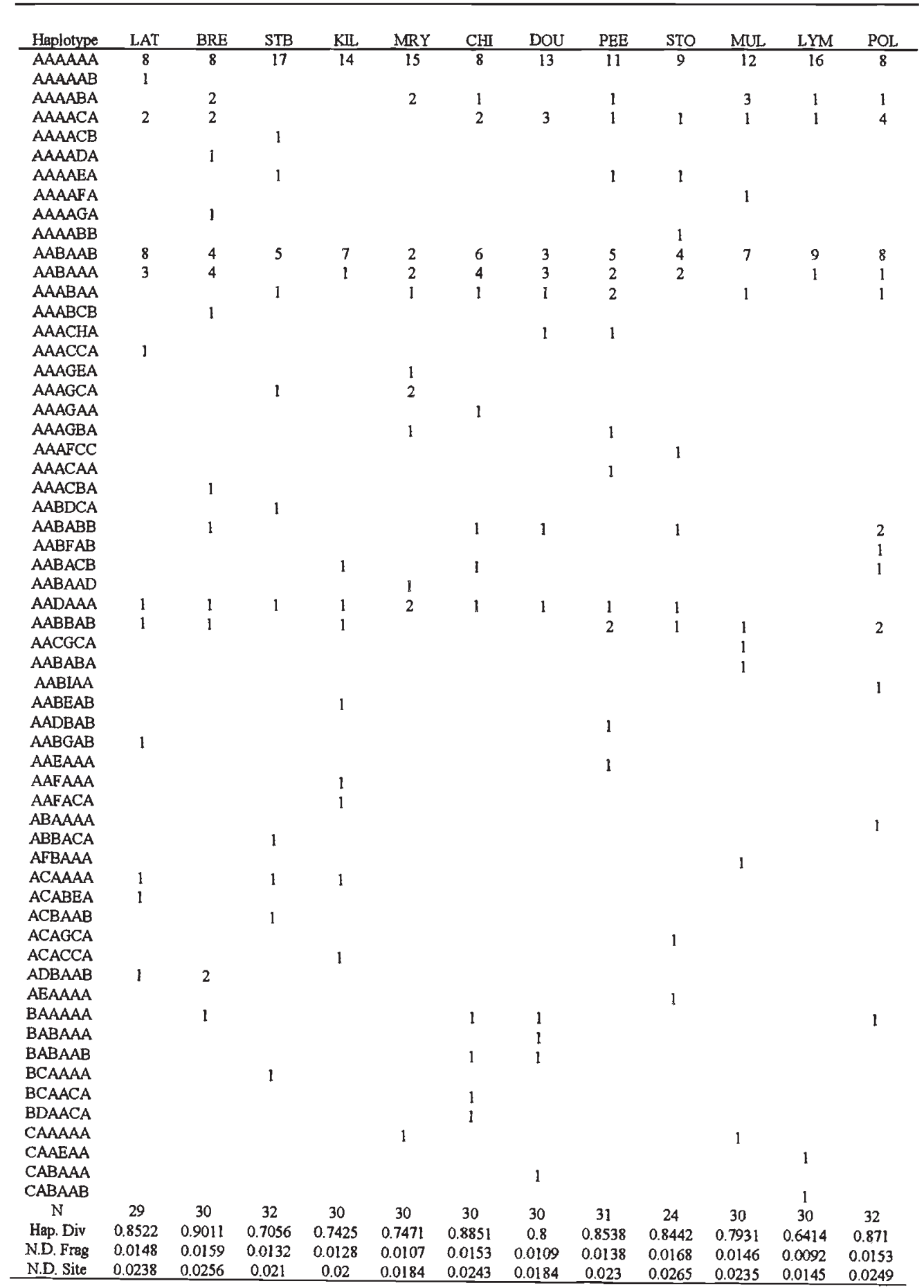

Population abbreviations as in Fig. 1. Order of restriction enzymes in composite haplotypes: Cfo I, HinfI, Msp I, Rsa I, Sau 3 AI and TaqI. 
populations or from single-enzyme haplotype data, Bonferroni procedure. Some haplotypes are when calculated values were adjusted via the confined to particular populations ('private haplo-

Table 2 Pma2-amplified mitochondrial DNA haplotypes in six populations of Pecten maximus

\begin{tabular}{|c|c|c|c|c|c|c|}
\hline Haplotype & $\mathrm{CHI}$ & $\mathrm{POL}$ & PEE & $\mathrm{KIL}$ & STB & MUL \\
\hline AAAAAA & 3 & 6 & & 4 & 6 & 3 \\
\hline AAAACA & 2 & & 1 & 1 & 6 & 4 \\
\hline AABAAA & 1 & & 1 & & 1 & \\
\hline BFAABA & 1 & & & 1 & & \\
\hline ACABAA & & & 1 & & & \\
\hline BBAABA & 3 & 4 & 1 & 2 & 3 & 4 \\
\hline AAAEAC & & & 1 & & & \\
\hline BEAABA & & 1 & & & 1 & \\
\hline AAAAFA & & 1 & & 1 & & \\
\hline AAAGCA & & 1 & & & & \\
\hline AAABAA & & 1 & & & & 1 \\
\hline DAAACA & & & & & 1 & \\
\hline AEAHAA & & & & & 1 & \\
\hline AACAAA & & & & & 1 & \\
\hline AABGAA & & & & & 1 & \\
\hline AAAIAA & & & & & 1 & \\
\hline AAAAEA & & & & & & 1 \\
\hline AAABCA & & & & & & 1 \\
\hline CBAABA & & & & 1 & & 1 \\
\hline BBBADA & & & & & & 1 \\
\hline AACACA & & & & & & 1 \\
\hline AGAAAA & & & & & & 1 \\
\hline AAACBA & & & & & & 1 \\
\hline AAAFEA & & & & & & 1 \\
\hline BEAABC & & & & 1 & & \\
\hline AAAACB & & & & 1 & & \\
\hline AABACA & 2 & & & 1 & 1 & \\
\hline AAADHA & & & & 1 & & \\
\hline BBAAAA & & & & 1 & & \\
\hline ABAACA & 1 & & & 1 & & \\
\hline BMBAAA & 1 & & & & & \\
\hline ANEACA & 1 & & & & & \\
\hline ADAACA & 1 & & & & & \\
\hline BHAABA & 1 & & & & & \\
\hline ADAAAA & 1 & & & & & \\
\hline BBAADA & & & 1 & & & \\
\hline $\mathrm{N}$ & 18 & 14 & 6 & 16 & 23 & 20 \\
\hline Hap. Div. & 0.9477 & 0.7692 & 1 & 0.9417 & 0.8696 & 0.9211 \\
\hline N.D. & 0.01089 & 0.01348 & 0.01348 & 0.01118 & 0.00802 & 0.00992 \\
\hline
\end{tabular}

Population abbreviations as in Fig. 1. Order of restriction enzymes in composite haplotypes: Dra I, HaeIII, HinfI, Msp I, Rsa I and Sau3AI.

(c) The Genetical Society of Great Britain, Heredity, 79, 178-189. 
types') but cannot be taken as evidence of population structure, only as an indication of considerable diversity. A UPGMA dendrogram of haplotype relatedness did not provide any evidence of geographical structure (Fig. 3).

Variation was extensive for the Pma1-amplified fragment with high values of haplotype diversity (the probability of encountering different haplotypes when two individuals are sampled from a popula- tion) and extensive nucleotide diversity within populations (Tables 1 and 2). Nucleotide diversities (corrected for within-population diversity below the diagonal) are shown in Tables 3 and 4 for the two fragments. A number of (corrected) pairwise nucleotide divergence values are negative, indicating that within-population diversity is greater than betweenpopulation differences, and thus there is little separation of populations on the basis of sequence
Fig. 3 UPGMA dendrogram generated from sequence divergence estimates for all Pecten maximus haplotypes. Presence of the haplotype in each population is indicated. For details of population abbreviations, see Fig. 1.

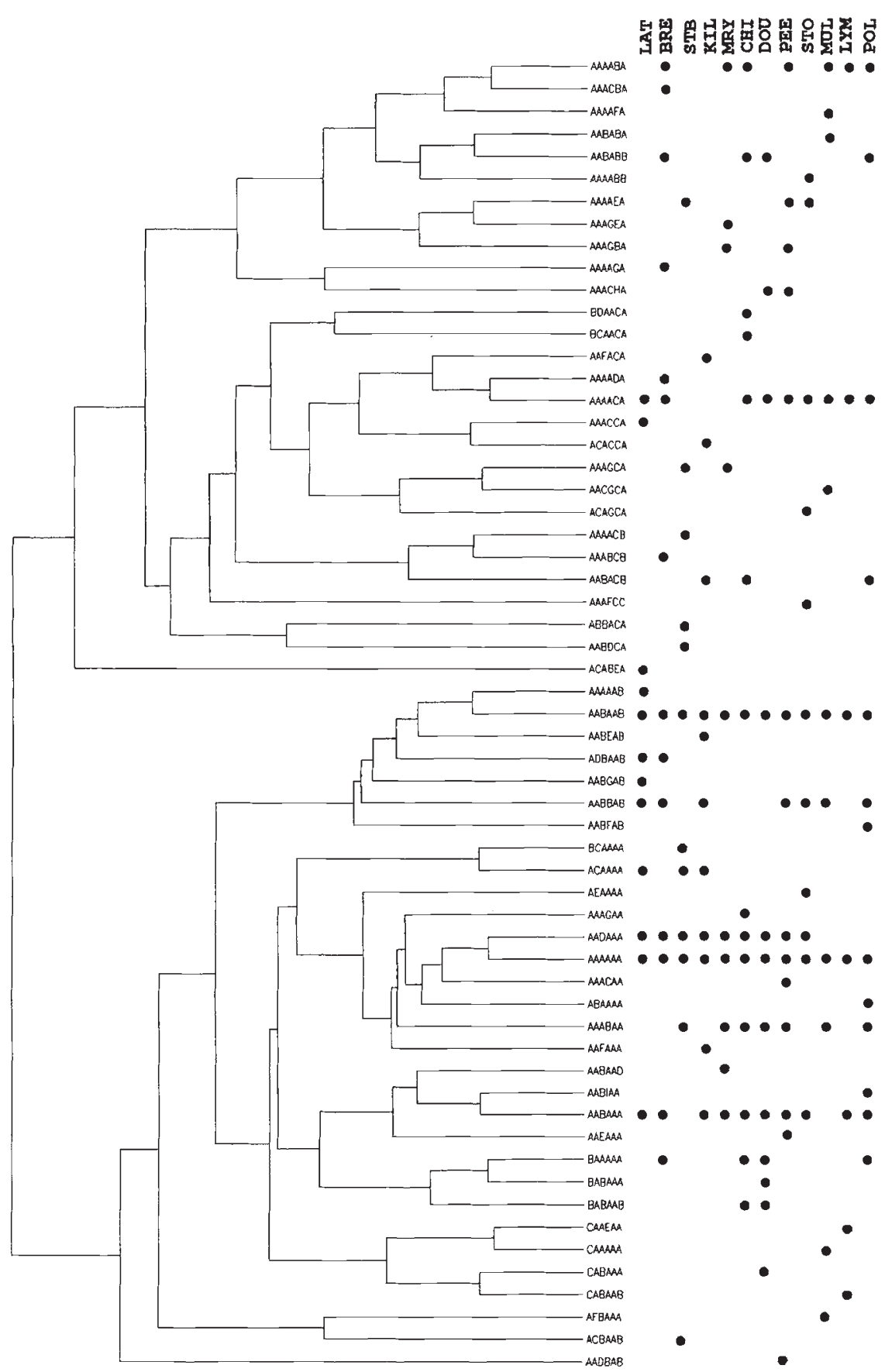

(C) The Genetical Society of Great Britain, Heredity, 79, 178-189. 


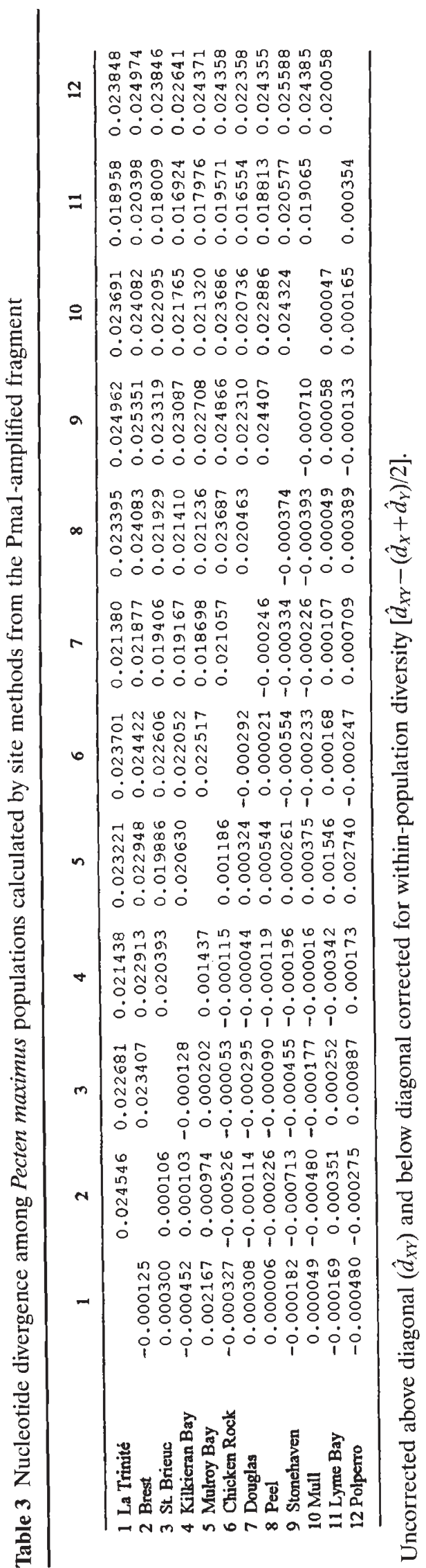

divergence. However, figures generated from Pma1 data in pairwise comparisons involving Mulroy Bay are consistently positive, indicating that betweenpopulation differences are greater than within-population diversity. A UPGMA dendrogram was constructed using the Pma1-derived nucleotide divergence data, correcting negative (artefactual) values to zero but, as a consequence of the multiple zero values in the matrix, this produced a number of equally likely trees. The consensus tree (Fig. 4) indicates that only the Mulroy Bay sample is separable, but that this separation is clearcut. Trees constructed from Pma2-derived values do not add further resolution (figure not shown). From the Pmal-derived data, an estimate of $F_{\mathrm{ST}}(\theta)$ of 0.005 was calculated.

\section{Discussion}

The presence of considerable length variation in $P$. maximus mtDNA causes substantial difficulties for the interpretation of RFLP patterns from whole mtDNA (Rigaa et al., 1993; Wilding, 1996). The application of PCR-RFLP circumvents these difficulties and, in addition, potentially permits the analysis of DNA extracted from minute quantities of tissue, perhaps even larvae. Here, primers are presented that permit reliable amplification of a highly polymorphic section of mtDNA. MtDNA of $P$. maximus studied by this method proved to be considerably polymorphic, with variation within populations often as great as or greater than that between sampling sites and numerous private haplotypes (haplotypes confined to single populations). The high values of haplotype diversity reflect this variation and, although these figures may not be strictly comparable with values based on data from whole mtDNA digests, the diversity levels in this study are of a similar level and distribution to other marine species. The observed pattern of two common haplotypes dominating the distribution and multiple, rarer or private haplotypes has been recognized in both Pacific oysters (Reeb \& Avise, 1990; Boom et al., 1994) and pollock (Shields \& Gust, 1995 ) and been attributed to a variety of possible causal mechanisms (Shields \& Gust, 1995). No diagnostic haplotypes or high-frequency haplotypes confined to any particular location were seen, and $\chi^{2}$ analysis failed to reveal any significant structure, nor was there any evidence of clustering of haplotypes with respect to area, suggestive of little phylogeographical structure. When allied to the low $\theta\left(F_{\mathrm{ST}}\right)$ estimate, the mtDNA data appear to be consistent with the conclusion from allozyme data (Beaumont

(C) The Genetical Society of Great Britain, Heredity, 79, 178-189. 
Table 4 Nucleotide divergence among Pecten maximus populations calculated by site methods from the Pma2-amplified fragment

\begin{tabular}{lrrrrrr} 
& 1 & $\mathbf{2}$ & $\mathbf{3}$ & $\mathbf{4}$ & $\mathbf{5}$ & $\mathbf{6}$ \\
\hline 1 Chicken Rock & & 0.009509 & 0.011609 & 0.010847 & 0.009500 & 0.010348 \\
2 Polperro & 0.000081 & & 0.009907 & 0.009137 & 0.008002 & 0.008592 \\
3 Peel & -0.000575 & -0.000820 & & 0.011543 & 0.010010 & 0.010833 \\
4 Kilkieran Bay & -0.000186 & -0.000438 & -0.000789 & & 0.009717 & 0.010177 \\
5 St. Brieuc & 0.000047 & 0.000005 & -0.000743 & 0.000115 & & 0.008885 \\
6 Mull & -0.000053 & -0.000352 & -0.000867 & -0.000372 & -0.000085 &
\end{tabular}

Uncorrected above diagonal $\left(\hat{d}_{X Y}\right)$ and below diagonal corrected for within-population diversity $\left[\hat{d}_{X Y}-\left(\hat{d}_{X}+\hat{d}_{Y}\right) / 2\right]$.

et al., 1993) that $P$. maximus conform to panmixia. Indeed, the low $F_{\text {ST }}$ estimate is typical of species with no observed genetic heterogeneity and far lower than figures at which restrictions to gene flow are detected, for example an $F_{\mathrm{ST}}$ value of 0.027 calculated from allozyme data in the limpet Patella vulgata was taken as evidence of genetic homogeneity, whereas $\theta$ of 0.427 from mtDNA was indicative of substantial population differentiation (Hurst \& Skibinski, 1995). Thus, at the haplotype level, there is little evidence of genetic heterogeneity among $P$. maximus populations. However, when the data are analysed at the nucleotide level, then for the Mulroy Bay sample the corrected nucleotide divergence was consistently positive in all pairwise comparisons (Table 3). Such a finding is indicative of genetic divergence (Ovenden, 1990). The suggested differentiation of the Mulroy Bay population could be explained by reproductive isolation of

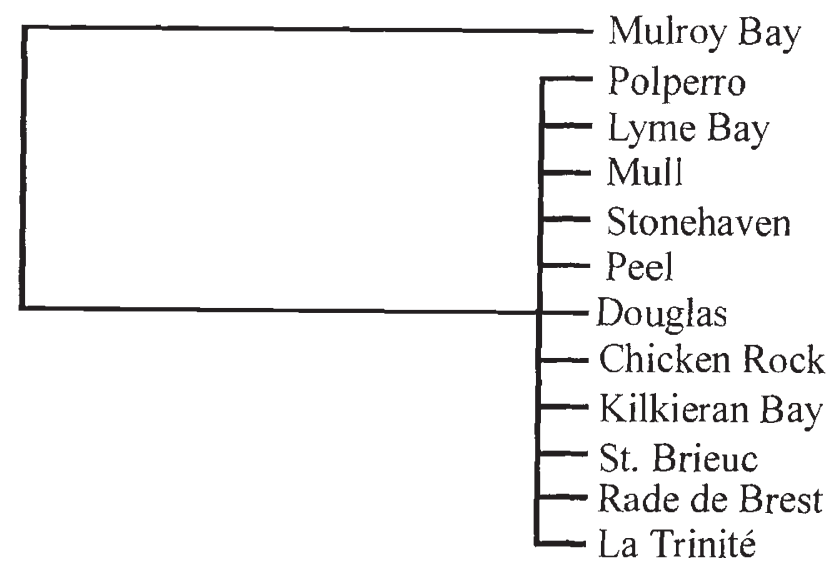

Fig. 4 Consensus dendrogram for Pecten maximus populations calculated from all equally likely UPGMA dendrograms using clustered nucleotide divergence values calculated from PCR-RFLP data on the Pma1-amplified fragment. The average sequence divergence of the Mulroy Bay sample from all other samples is 0.107 per cent. the individuals within this population and genetic drift acting on haplotype frequencies. MtDNA has increased susceptibility to genetic drift as a result of the lowered effective population size (half that of nuclear genes for such a hermaphroditic species), which could explain why mtDNA reveals population structure not uncovered by allozyme (nuclear) loci. Mulroy Bay is a semi-enclosed sea lough with two entrance sills acting to reduce water movement in and out of the basin. This is probably an effective containment mechanism for larvae, which will promote genetic differentiation. The shell colour of $P$. maximus juveniles has previously been suggested as indicating that Mulroy Bay scallops may indeed be variant (Minchin, 1991). Although the mtDNA divergence values add support to this hypothesis, the Mulroy Bay sample in this study, which came from a single spatfall ongrown elsewhere, may not be representative of the population as a whole, whether because of temporal effects (variation in genetic composition of recruits between settlements) or postcollection mortality effects. Temporal variation in the composition of recruits has been documented in other marine species (Watts et al., 1990; Hedgecock, 1994). Convincing evidence that Mulroy Bay scallops are self-recruiting will only be possible through the analysis of a sample of native adults. The possible self-recruiting nature of the Mulroy Bay population has implications for the management of the population because, although Mulroy Bay $P$. maximus are no longer heavily fished (Minchin, pers. comm., 1983), the population has been proposed as a suitable site for the collection of scallop spat for reseeding efforts (Slater, pers. comm., 1995).

The demonstration of substantial sequence divergence between populations of $P$. maximus represents the first genetic evidence that some populations may be, to some extent, reproductively isolated. Mulroy Bay $P$. maximus have not previously been analysed at the molecular level, but our own studies using allozyme electrophoresis (C. S. Wilding et al., in 
preparation) provide little evidence for the distinctness of this population on the basis of allozyme frequencies. Discrepancies between results based on protein electrophoresis and DNA-based markers, either in the ability to separate populations or in the magnitude of differentiation, have previously been recognized in a number of species, for example Drosophila melanogaster (Begun \& Aquadro, 1993), mussels Mytilus galloprovincialis (Karakousis \& Skibinski, 1992) and the American oyster Crassostrea virginica. In this species, Atlantic and Gulf of Mexico populations appear genetically homogeneous for allozyme markers but exhibit a pronounced genetic break for mtDNA and anonymous singlecopy nuclear DNA markers (Karl \& Avise, 1992). This was attributed to balancing selection maintaining similar allele frequencies in populations experiencing little gene flow. Such a mechanism may be an alternative explanation for why $P$. maximus appear panmictic on the basis of allozyme data, despite possible reproductive isolation or restrictions to gene flow.

The lack of significant differentiation of the St Brieuc scallops at the mtDNA level is surprising, if this population is indeed reproductively isolated as has previously been suggested (Paulet et al., 1988; Cochard \& Devauchelle, 1993; Mackie \& Ansell, 1993). If population differentiation is present, then mtDNA is expected to reveal more differences than allozymes owing to high variability and lowered effective population size, and failure to establish that differences are present questions whether the population is indeed genetically different. If the reproductive data are truly an indication of genetic isolation, then the suitability of the marker is brought into question and analysis with alternative systems, e.g. microsatellites, may prove fruitful. It is noteworthy that variation in the frequency of haplotype AAAAAA for Pma1 is similar to that of PT-A allele frequencies in $A$. opercularis, in which substantial population subdivision, including separation of the St Brieuc population, is observed (Beaumont, 1982). Thus, the haplotype frequency at St Brieuc appears to be more similar to the Irish Sea populations than to the neighbouring Rade de Brest population, which is itself similar to the sample from $\mathrm{La}$ Trinité (for queen scallops, a population from nearby Belle Isle was studied). All Irish Sea samples are similar (although Chicken Rock appears to have a lower frequency of this haplotype). There are, however, no great differences between Irish Sea populations and those from the west coasts of Ireland and Scotland. This similarity in pattern is by no means convincing, but it may be indicative that underlying differentiation does exist and that further study of St Brieuc P. maximus may prove productive.

\section{Acknowledgements}

We are grateful to Dr A. Brand (Port Erin Marine Laboratory), Dr G. Burnell (University College, Cork), Dr P. Dare (MAFF, Lowestoft), Dr P. G. Fleury (IFREMER, Brest) and T. Howell (SOAFD, Aberdeen) for provision of scallops. C.S.W. was supported by NERC grant GT4/92/275 A.

\section{References}

ANSEll, A. D., DAO, J.-C. AND MASON, J. 1991. Three European scallops: Pecten maximus, Chlamys (Aequipecten) opercularis and $C$. (Chlamys) varia. In: Shumway, S. E. (ed.) Scallops: Biology, Ecology and Aquaculture, pp. 715-751. Elsevier, Amsterdam.

BARTLETT, S. E. AND DAVIDSON, w. s. 1995. Genetic analysis of Salmo using mtDNA AMPFLPs. Aquaculture, 137, 47-48.

BEAUMONT, A. R. 1982. Geographic variation in allele frequencies at three loci in Chlamys opercularis from Norway to the Brittany coast. J. Mar. Biol. Ass. U.K., 62, 243-261.

BEAUMONT, A. R. AND BARNES, D. A. 1992. Aspects of veliger larval growth and byssus drifting of the spat of Pecten maximus and Aequipecten (Chlamys) opercularis. ICES J. mar. Sci., 49, 417-423.

BEAUMONT, A. R., MORVAN, C., HUELVAN, S., LUCAS, A. AND ANSELL, A. D. 1993. Genetics of indigenous and transplanted populations of Pecten maximus: no evidence for the existence of separate stocks. J. Exp. Mar. Biol. Ecol., 169, 77-88.

BEGUN, D. J. AND AquAdro, C. F. 1993. African and North American populations of Drosophila melanogaster are very different at the DNA level. Nature, 365, 548-550.

BOOM, J. D. G., BOULDING, E. G. AND BECKENBACH, A. T. 1994. Mitochondrial DNA variation in introduced populations of Pacific oyster, Crassostrea gigas, in British Columbia. Can. J. Fish. Aquat. Sci., 51, 1608-1614.

BOUlDING, E. G., BOOM, J. D. G. AND BECKENBACH, A. T. 1993. Genetic variation in one bottlenecked and two wild populations of the Japanese scallop (Patinopecten yessoensis): empirical parameter estimates from coding regions of mitochondrial DNA. Can. J. Fish. Aquat. Sci., 50, 1147-1157.

BRAND, A. R. 1991. Scallop ecology: distributions and behaviour. In: Shumway, S. E. (ed.) Scallops: Biology, Ecology and Aquaculture, pp. 517-584. Elsevier, Amsterdam.

CHOW, S. AND INOUE, s. 1993. Intra- and interspecific restriction fragment length polymorphism in mitochondrial genes of Thunnus tuna species. Bull. Natl. Res. Inst. Far Seas Fish., 30, 207-225. 
COCHARD, J. C. AND DEVAuChElle, N. 1993. Spawning, fecundity and larval survival and growth in relation to controlled conditioning in native and transplanted populations of Pecten maximus (L.): evidence for the existence of separate stocks. J. Exp. Mar. Biol. Ecol., 169, 41-56.

CRONIN, M. A., SPEARMAN, W. J., WILMOT, R. L., PATTON, J. C. AND BICKHAM, J. W. 1993. Mitochondrial DNA variation in chinook (Oncorhynchus tshawytscha) and chum salmon $(O$. keta) detected by restriction enzyme analysis of polymerase chain reaction (PCR) products. Can. J. Fish. Aquat. Sci., 50, 708-715.

CRONIN, M. A., HILls, S., BORN, E. W. AND PATTON, J. C. 1994. Mitochondrial DNA variation in Atlantic and Pacific walruses. Can. J. Zool, , 72, 1035-1043.

DARE, P. J., DARBY, C. D., DURANCE, J. A., AND PALMER, D. W. 1994. The distribution of scallops (Pecten maximus) in the English Channel and Celtic Sea in relation to hydrographic and substrate features affecting larval dispersal and settlement. In: Bourne, N. F., Bunting, B. L. and Townsend L. D. (eds) Proceedings of the 9 th International Pectinid Workshop, Nanaimo, B.C., Canada, 22-27 April 1993. Can. Tech. Rep. Fish. Aquat. Sci., 2, 20-27.

FISHER, C. AND SKIBINSK1, D. O. F. 1990. Sex-biased mitochondrial DNA heteroplasmy in the marine mussel Mytilus. Proc. R. Soc. B, 242, 149-156.

GJetvaJ, B., COOK, D. I. AND zouros, E. 1992. Repeated sequences and large-scale size variation of mitochondrial DNA: a common feature among scallops (Bivalvia: Pectinidae). Mol. Biol. Evol., 9, 106-124.

GOUDET, J. 1995. FSTAT (Version 1.2). A computer program to calculate $F$-statistics. J. Hered., 86, 485-486.

HALL, H. J. AND NAWROCKI, L. W. 1995. A rapid method for detecting mitochondrial DNA variation in the brown trout, Salmo trutta. J. Fish. Biol., 46, 360-364.

HEDGECOCK, D. 1994. Temporal and spatial genetic structure of marine animal populations in the California current. CALCOFI Rep., 35, 73-81.

HOLMES, D. S. AND QUiGLEY, M. 1981. A rapid boiling method for the preparation of bacterial plasmids. Analyt. Biochem., 114, 193-197.

HURST, C. D. AND SKIBINSK1, D. O. F. 1995. Comparison of allozyme and mitochondrial DNA spatial differentiation in the limpet Patella vulgata. Mar. Biol., 122, 257-263.

KARAKOUSIS, Y. AND SK1BINSKI, D. O. F. 1992. An analysis of allozyme, mitochondrial DNA and morphological variation in mussel (Mytilus galloprovincialis) populations from Greece. Experientia, 48, 878-881.

KARL, S. A. AND AVISE, J. C. 1992. Balancing selection at allozyme loci in oysters: implications from nuclear RFLPs. Science, 256, 100-102.

McELROY, D., MORAN, P., BERMINGHAM, E. AND KORNFIELD, I. 1992. REAP: An integrated environment for the manipulation and phylogenetic analysis of restriction data. J. Hered., 83, 157-158.

MACKIE, L. A. AND ANSELL, A. D. 1993. Differences in reproductive ecology in natural and transplanted popu- lations of Pecten maximus: evidence for the existence of separate stocks. J. Exp. Mar. Biol. Ecol., 169, 57-75.

MASON, J. 1983. Scallop and Queen Fisheries in the British Isles. Fishing News Books, Farnham, England.

MINCHIN, D. 1991. Observations on shell colour in the scallop, Pecten maximus (L.). J. Conchol., 34, 41-46.

MITTON, J. B. 1994. Molecular approaches to population biology. Ann. Rev. Ecol. Syst., 25, 45-69.

MORITZ, C., DOWLING, T. E. AND BROWN, w. M. 1987. Evolution of animal mitochondrial DNA: relevance for population biology and systematics. Ann. Rev. Ecol. Syst., 18, 269-292.

NEı, M. 1987. Molecular Evolutionary Genetics. Columbia University Press, New York.

OVEndEN, J. R. 1990. Mitochondrial DNA and marine stock assessment: a review. Aust. J. Mar. Freshw. Res., 41, 835-853.

PAULET, Y. M., LUCAS, A. AND GERARD, A. 1988. Reproduction and larval development in two Pecten maximus (L.) populations from Brittany. J. Exp. Mar. Biol. Ecol., 119, 145-156.

REEB, C. A. AND AVISE, J. C. 1990. A genetic discontinuity in a continuously distributed species: mitochondrial DNA in the American oyster, Crassostrea virginica. Genetics, 124, 397-406.

REPIN, P. V. AND BRYKOV, V. A. 1992. Mitochondrial DNA from sea scallops (Pectinidae) with unusual properties. Genetika, 29, 460-467.

RIGAA, A., LE GAL, Y., SELlOS, D. AND MONNEROT, M. 1993. Mapping and repeated sequence organization of mitochondrial DNA in scallop, Pecten maximus. Mol. Mar. Biol. Biotechnol., 2, 218-224.

RIGAA, A., MONNEROT, M. AND SEllos, D. 1995. Molecular cloning and complete nucleotide sequence of the repeated unit and flanking gene of the scallop Pecten maximus mitochondrial DNA: putative replication origin features. J. Mol. Evol., 41, 189-195.

ROFF, D. A. AND BENTZEN, P. 1989. The statistical analysis of mitochondrial DNA polymorphisms: $\chi^{2}$ and the problem of small samples. Mol. Biol. Evol., 6, 539-545.

ROHLF, F. J. 1990. NTSYS-PC: Numerical Taxonomy and Multivariate Analysis System. Exeter Publishing, Setauket, NY.

SAMBROOK, J., FRITSCH, E. F. AND MANIATIS, T. 1989. Molecular Cloning: A Laboratory Manual, 2nd edn. Cold Spring Harbor Laboratory Press, New York.

SHIELDS, G. F. AND GUST, J. R. 1995. Lack of geographic structure in mitochondrial DNA sequences of Bering Sea walleye pollock, Theragra chacogramma. Mol. Mar. Biol. Biotechnol., 4, 69-82.

SINCLAIR, M., MOHN, R. K., ROBERT, G. AND RODDICK, D. L. 1985. Considerations for the effective management of Atlantic scallop populations. Can. Tech. Rep. Fish. Aquat. Sci., 1382, 1-113.

SNYDER, M., FRASER, A. R., LAROCHE, J., GARTNER-KEPKAY, K. E. AND ZOUROS, E. 1987. Atypical mitochondrial DNA from the deep-sea scallop Placopecten magellanicus. Proc. Natl. Acad. Sci. U.S.A., 84, 7595-7599. 
WATTS, J., JOHNSON, M. S. AND BLACK, R. 1990. Effects of recruitment on genetic patchiness in the urchin Echinometra mathaei in Western Australia. Mar. Biol., 105, 145-161.

WILding, C. s. 1996. Population Genetics of the Scallop Pecten maximus: Morphological, Allozyme Electophoresis and Mitochondrial DNA Approaches. PhD thesis, University of Wales, Bangor.

ZHANG, D.-X. AND HEWITT, G. M. 1996. Nuclear integrations: challenges for mitochondrial DNA markers. Trends Ecol. Evol, 11, 247-251. 